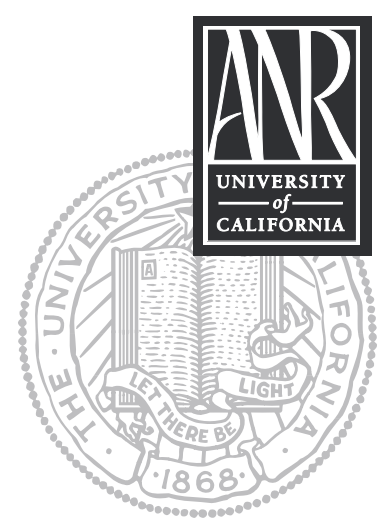

UNIVERSITY OF CALIFORNIA

Division of Agriculture and Natural Resources http://anrcatalog.ucdavis.edu

\title{
FOREST STEWARDSHIP SERIES 18 Stewardship Objectives and Planning
}

LAURIE LITMAN, InfoWright, Stockton, CA; YANA VALACHOVIC, UCCE Forest Advisor, Humboldt and Del Norte Counties

\section{FOREST STEWARDSHIP GOALS AND OBJECTIVES}

The first step in managing your forest effectively is to define your goals, that is, your vision for your property. Your goals will be determined by you and your family. If others are involved in your land decisions, such as your heirs, extended family, or other partners, involve them in this planning process, too.

Goals are general statements. The number of goals you formulate should correspond with what you feel is necessary to communicate your vision. For example, one of your goals may be to reduce the fire hazard of your property, another might be to increase wildlife species diversity, and a third might be to generate

\section{Objective}

Understand the value of stewardship planning and how to prepare your own plan.

\section{Competencies}

- Develop a management plan for communicating your goals and objectives to your family, agencies, and resource management professionals.

- Begin a long-term record of your management actions.

- Set priorities for action and understand the steps necessary to accomplish your goals.

- Update plans as conditions change.

\section{Related Forest Stewardship Series}

\section{Publications}

- Laws and Regulations Affecting Forests, Part I: Timber Harvesting, ANR Publication 8249

- Laws and Regulations Affecting Forests, Part II: Activities Other Than Timber Harvesting, ANR Publication 8250

- Economic Considerations in Forest Stewardship, ANR Publication 8251

- Forest Taxation, Estate Planning, and Conservation Easements, ANR Publication 8252

- Professional Assistance, ANR Publication 8254

- Technical and Financial Assistance, ANR Publication 8253 income by enhancing the recreational values of your land. Whatever the goals, they should be based on your personal values and needs. They should also be realistic and within the potential of your property. Consequently, part of the stewardship planning process includes learning about your property.

1. Start with identifying your goals. Write them down to help you define, remember, and communicate them to others.

2. Prioritize your goals. This will help you figure out where to start and where to put your money and effort. You may find that some goals conflict with others. In that case, you will need to find creative solutions or compromises to reconcile them.

3. While goals are the general vision, objectives are the concrete steps you take to reach your goals. For example, if your goal is to increase habitat for deer, an objective may be to thin or burn some areas of your land to promote early-successional brushy vegetation. Be specific and include costs and a timeline when identifying objectives. Statements of objectives should identify specific quantities and times, such as "restore 12 acres of riparian vegetation by fall 2010." Specific statements will help you track your progress.

While the vision for your property is entirely up to you, advice from experts can be very helpful in determining what is possible and deciding how to best achieve that vision. You may want to consult with a forester, wildlife biologist, soil scientist, or other professionals to discuss your goals, applicable regulations, and various way to achieve your goals. Professionals can also provide an idea of costs for activities and may be able to help you find cost-share funding to accomplish them. Be sure to choose professionals who will listen to you and address your goals. 


\section{THE BIG PICTURE: LANDSCAPE-LEVEL PLANNING}

After you have defined your goals and objectives, step back and consider the bigger picture. How do your goals fit together at the landscape level? Suppose you have two goals, one to reduce the risk of wildfire and the other to increase habitat for wildlife. If you plan to thin the forest for fire safety, how will that affect your goal to provide vegetative corridors for wildlife? Landscape-level planning looks at the entire property and takes into account all your goals and objectives.

Taking that concept a step further, now look at how your landscape planning fits in with the rest of the watershed and the region. What are the important issues and priorities in your area? How do your goals fit in with those?

\section{TYPES OF MANAGEMENT PLANS}

Several types of plans can help guide your land management decisions. The simplest you may prepare yourself. For timber harvest plans or management plans required for participation in cost-share programs, you will need to rely on the assistance of a registered professional forester (RPF).

\section{Stewardship or Management Plan}

The purpose of a stewardship plan is to put down on paper the most important aspects of your property's physical features, as well as your management philosophy, objectives, and vision for the future. Even if the plan is only a few pages of text and maps, it can provide important guidance and continuity in the management of your property. Most state or federal assistance programs require a management plan.

\section{Timber Harvest Plan (THP) or Nonindustrial Timber Management Plan (NTMP)}

A THP or NTMP is required when a landowner engages in commercial timber harvesting. Both of these are state-approved environmental review documents that must be prepared by an RPF. These plans generally discuss the timber and watercourse components of the property and a range of other important issues. Your broader vision, goals, and objectives are best written down elsewhere.

\section{THE STEWARDSHIP PLAN}

Stewardship planning takes into account the various resources present on the property (e.g., timber, fisheries, wildlife, botanical resources, watershed values, etc.), and the needs of present and future generations. A commitment to good stewardship is a commitment to manage the forest thoughtfully.

\section{Why Create a Stewardship Plan?}

Your stewardship plan is the blueprint that guides the management of your property. Analogous to a business plan for your forest, it helps you define where you are, where you want to go, and how best to get there. It is a creative document-a chance to combine your dreams with the practical framework needed to achieve them. The stewardship plan can guide you in making decisions and taking the actions that will fulfill your personal goals.

You can use your stewardship plan as the basis for applying for funding and preparing timber harvest plans. Although each of these requires its own set of information presented in a particular way, much of the information will be available at your fingertips from your stewardship plan. A stewardship plan can also be of assistance to any professionals you consult to help with bank loans, timber management planning, and the like.

A stewardship plan can be as simple or as complex as you wish to make it, depending on how you expect to use the plan and how much detail you feel is neces- 
sary. Larger, more complex forests may require more work. No matter what level of detail you choose, none of the effort will be wasted. The knowledge you gain about your property will help in your day-to-day decision making. Articulating your goals will help guide your short-term activities to efficiently and cost-effectively achieve your long-term goals. It is also a wonderful way to communicate your vision to the next generation of managers of your property.

Nothing in a stewardship plan is set in stone; this is simply your own personal guide to your goals. As conditions change-in your life, in your goals, on your property, in the economy-you may want to adjust the plan accordingly. It is a good idea to revisit the stewardship plan on a regular basis, perhaps once a year, to keep the plan current and your management activities on track.

\section{How to Organize Your Plan}

Write your stewardship plan down: the process of putting the information on paper will help you clarify your thoughts. In addition, a written plan is the best way to share your ideas with your family, forester, banker, or others. Remember, however, that you are developing this plan for your own needs, so write only what you feel is necessary. Since forest stewardship plans are developed for a variety of reasons, there are a number of ways to write them. The comprehensive outline that follows contains many sections and topics. You may choose to include all of them or only those that address your personal goals and objectives. A forest stewardship plan is not a timber harvest plan. A timber harvest plan has specific regulatory requirements, must be written by an RPF, and is beyond the scope of what is presented here. If you have writer's block or a hard time putting words on paper, a well-organized list may be all you need to help you in your management planning. Ideas are more important than complex sentences and paragraphs. In the sections that follow, we offer a structure, specific subjects to consider, and sample language to stimulate your thinking process and serve as a template, as needed.

\section{Sample Plan Outline}

\section{Cover page}

- Date of plan.

- Landowner name, address, phone, fax, and e-mail.

- Tract name or number.

- Total tract acreage.

- Total forested acreage.

- Legal description from your deed.

- Latitude and longitude.

- Land use classification (zoning).

- Watershed.

- Fire protection district.

- Seed zone (California zone that describes compatible latitude and elevation for tree seed that is most suitable for your property-see Forest Stewardship Series 7: Forest Regeneration, ANR Publication 8237).

\section{Introduction}

- Explain the plan's purpose and how it relates to the landowner's values.

- Describe property and give a brief history of the land. 


\section{Description}

- Landowner information.

- Legal description.

- Assessor's parcel number(s).

- Boundary map.

- Property corners.

- Adjacent property owners.

- Tax status.

- Maps of the property showing vegetation cover types, soil types, topography, access with roads and culverts, water features, and other resource sites. Aerial photos can be included.

\section{Goals and Objectives}

- Describe what you want to achieve on the property. Include goals, which are broad statements, and objectives, which are specific and measurable (see table 1 for ideas on possible goals and objectives). Repeat the following outline for all goals and their related objectives:

Goal \#1:

Objective \#1: Timeline for action and estimated costs

Objective \#2: Timeline for action and estimated costs

Objective \#3: Timeline for action and estimated costs

Example:

Goal: Increase water availability and storage in the northwestern side of the property for fire protection and other uses.

Objective \#1: By next year, develop a spring site and water storage capabilities.

Estimated cost: $\$ 2,000$ for 1,000-gallon storage tank, hose, fittings and spring box.

\section{Vegetation}

- Describe existing meadows and forest types, including riparian areas. Include a map of forest types. Give the following details for each type: acreage, species mix, density, site index, size class, age, elevation, slope, and aspect. Gather forest inventory data in as much detail as needed to make your decisions.

- List significant historical events for each stand: date of origin, planted or natural, past timber or product sales, timber stand improvements, reforestation, vegetation management, and loss events such as fire, insects, and diseases.

- Compile a list of management opportunities for each vegetation type.

\section{Wildlife Habitat}

- Species inventory, sensitive species, habitat components, special protection measures needed, and improvement activities needed. Record the presence and abundance of snags and downed woody debris. Describe recruitment and retention goals to enhance, maintain, or restore habitat.

\section{Threatened and Endangered Species}

- Identify any officially listed or potentially threatened and endangered plant or animal species that could be present on the property. This will likely require consultation with a wildlife biologist and a botanist. List activities to maintain or improve species habitat.

\section{Soils}

- Identify major soil types and their associated vegetation types, topographic and geological features, and characteristics such as site index and slope stability. Identify permanent skid trails to reduce soil compaction associated with timber harvest. Identify erosion, drainage, and other soil problems. Find the causes of problems and identify how they will be addressed. 
Table 1. Example goals and objectives for forest property

\begin{tabular}{|c|c|}
\hline Goal & Objective \\
\hline \multicolumn{2}{|l|}{ Long-term Planning Goals } \\
\hline $\begin{array}{l}\text { Increasing certainty and sustain- } \\
\text { ability (the long-term conserva- } \\
\text { tion and stewardship) for your } \\
\text { forest }\end{array}$ & $\begin{array}{l}\text { Discuss and write down family goals for ownership. } \\
\text { Develop a management (stewardship) plan. } \\
\text { Develop long-term relationships with a forester and other specialists. } \\
\text { Develop an estate plan: contact a tax accountant and lawyer. } \\
\text { Explore the benefits of a conservation easement: contact a tax accountant } \\
\text { and lawyer. } \\
\text { Identify cost-share funding possibilities. } \\
\text { Develop an NTMP or other state-approved harvest permit. } \\
\text { Explore incentive programs such as certification or carbon banking for } \\
\text { your land. }\end{array}$ \\
\hline
\end{tabular}

\section{Safety Goals}

Reducing fuel hazards throughout property and adjacent to structures

Get involved with the local fire safe community group.

Learn how CAL FIRE and other local firefighters are likely to respond to a

\section{Conservation Goals}

Water quality protection, restoration, and/or enhancement

Soil protection, restoration, and/ or enhancement; improving soil fertility

Wildlife protection, restoration, and/or enhancement. fire on your property.

Develop an understanding of likely ignition points and wind patterns.

Develop a fire response that includes

- fuel breaks

- property access and evacuation routes

- water storage

- fire-safing your home

- thinning of understory; prescribed burns

- creating defensible space adjacent to your home, other buildings, and other places of value

Inventory riparian areas for amount and species composition of the riparian canopy.

Inventory quality and location of large woody debris.

Inventory road conditions and interactions with streams.

Monitor stream temperatures.

Plant more trees where deficient.

Develop a road management plan to

- stormproof roads

- remove any unneeded crossings and upgrade necessary ones

- move roads if necessary

- stabilize any human-caused erosion sources

- remove or repair culverts that block fish passage, are undersized, or are falling apart

- determine if you are in a TMDL-impaired watershed

Develop recruitment and retention policy for snags and coarse woody debris inputs into soils over time.

Prevent and minimize soil compaction in timber activities or other construction projects; designate permanent skid trails; designate leastimpacting yarding equipment.

Stabilize and revegetate erosive areas.

Inventory wildlife species on your property; determine what was historically found there; determine which wildlife species you are managing for and those species' habitat requirements (e.g., enhance, maintain, and retain ecotones, oak trees, snags, downed wood, mosaics, etc.).

Enhance structural complexity through thinnings.

Encourage tree and shrub species diversity.

Inventory condition of riparian migration corridors and connectivity between habitats.

Plant conifers in riparian areas if deficient.

\section{Potential resources}

\section{Local land trusts}

Preserving Family Lands in California, http://www .californiaoaks.org/html/conservation.html

Estate Planning for Forest Landowners (Haney and Siegel 1993)

Preserving Family Lands II, http://www.stevesmall.com

Timber Tax Web site, http://www.timbertax.org

Cost Share Directory, http://ceres.ca.gov/foreststeward/ $\mathrm{html} /$ financial.html

Forest Stewardship Council, Tree Farm, Sustainable Forestry Initiative
Fire Safe Council, http://www.firesafecouncil.org

"Fire Safe Landscaping," CAL FIRE Tree Notes no. 17, http://www.ceres.ca.gov/foreststeward/pdf/treenote17. pdf

Home Landscaping for Fire, UC ANR Publication 8228, http://anrcatalog.ucdavis.edu/pdf/8228.pdf
California Salmonid Stream Habitat Restoration Manual www.dfg.ca.gov/nafwb/manual.html

Plant It Right, http://wawater.wsu.edu

Handbook for Forest and Ranch Roads, Mendocino County RCD, http://www.krisweb.com/biblio/gen mcrcd_weaveretal_1994_handbook.pdf

Landowners Guide to Building Forest Access Roads, http://www.na.fs.fed.us/spfo/pubs/stewardship laccessroads/accessroads.htm

Nursery Sources for California Native Plants, California Geological Survey publ. OFR-90-04, http://www.consrv. ca.gov/CGS/information/publications/pub_index/issue papers.htm

Forest Ecosystem Stewardship, Oregon State University College of Forestry, \$7, 541-737-4271

Sediment Delivery Inventory and Monitoring, UC ANR Publication 8014, http://anrcatalog.ucdavis. edu/pdf/8014.pdf

Habitat Sweet Habitat, Forestland Steward 10, http:// www.ceres.ca.gov/foreststeward/pdf/newslettr10.pdf

Forest Ecosystem Stewardship, Oregon State University College of Forestry, \$7, 541-737-4271

Riparian Forest Wildlife, Montana State University Extension, \$5, 406-994-3273 


\begin{tabular}{|l|}
\hline Goal \\
\hline $\begin{array}{l}\text { Protecting ecosystems from non- } \\
\text { native species }\end{array}$ \\
\hline $\begin{array}{l}\text { Protecting against pests and dis- } \\
\text { eases }\end{array}$ \\
\hline $\begin{array}{l}\text { Protecting historical and pre-his- } \\
\text { torical values }\end{array}$ \\
\hline
\end{tabular}

\section{Economic Goals}

\section{Timber harvesting}

Increasing inventory and stand productivity

Improving stand structure and the quality of future crop trees

Enhancing the quality of hardwoods

Firewood production
Special products production
$\begin{aligned} & \text { Other opportunities (e.g. develop } \\ & \text { recreational, hunting, photogra- } \\ & \text { phy, other potential uses) }\end{aligned}$

\section{Quality of Life Goals}

Aesthetics

A

Protect or enhance special or spiritual places.

\section{Recreation}

\section{Landscape-scale Goals}

Integrate goals at the property, watershed, regional and community levels

\section{Objective}

Inventory and map exotic pest plants.

Develop a Weed Management Plan.

Take steps to control exotic weeds using integrated pest management strategies.

Inventory property for insects and diseases.

Make plans to take remedial actions if needed.

Inventory and protect prehistoric and historic resources older than 50 years.

\section{If you do not have a forester, select one.}

Develop a harvest schedule to realize economic and ecological goals now and for future generations.

- Explore timber stand improvement opportunities (precommercial thinning, pruning, commercial thinning, etc).

- Determine if there are tree planting needs (understocked areas, planting to increase diversity, etc).

Inventory property for species of interest that can be sustainably harvested.

Explore certification options.

Develop markets for firewood.

Determine which products there are markets for (greenery, mushrooms, etc.).

Develop a marketing plan. Identify potential markets.

Enhance potential features (create hiking trails, mountain bike trails, etc.), that follow guidelines for roads and protect water quality.

Determine what is aesthetically pleasing to you.

Potentially thin fuels in highly visible areas.

Utilize thinnings to promote structural development and complexity so as to take on older forest characteristics.

Establish retention goals in highly visible areas.

Limb branches along hiking trails.

Remove invading conifers in oak woodlands.

Identify and maintain places with significance to you.

Develop a picnic area in your favorite place.

Enhance recreation potential (develop hiking or biking trails, hunting blinds, etc.).

\section{Potential resources}

Create an Integrated Weed Management Plan, http:// parks.state.co.us/cnap/IWM_handbook/IWM_index. htm

Nature Conservancy, http://tncweeds.ucdavis.edu

\section{CalEPPC, http://www.caleppc.org}

California Native Plant Society, http://www.cnps.org/ programs/conservation/exotics.htm

CAL FIRE Tree Notes,

http://ceres.ca.gov/foreststeward/html/treenotes.html

CAL FIRE Archaeology, http://www.fire.ca.gov/ or http:// www.indiana.edu/ e472/cdf/

CAL FIRE for info on regulations, yield taxes, assistance programs, etc.; http://www.fire.ca.gov

Managing Your Redwood Forest, IHRMP, http://danr. ucop.edu/ihrmp/allpubs.html

Guidelines for Managing California's Hardwood Rangelands, IHRMP http://danr.ucop.edu/ihrmp/allpubs.html

Contact state nurseries, at http://www.fire.ca.gov/php/ rsrc-mgt_statenurseries.php
Working Your Woods, Institute for Sustainable Forestry, http://newforestry.org/publications/main

Talk to neighbors, local watershed groups, or agencies to find out about local priorities and concerns.

Determine if there are existing watershed recovery plans (e.g. TMDLs) or nearby habitat conservation plans (HCPs) and evaluate actions.

Lay out your goals on maps or spatially within a geographic information system (GIS).

Note: This table provides examples of timber and non-timber goals, objectives, and available resources to help stimulate ideas that may or may not be appropriate for your property. This list is certainly not complete, but it can be used as a starting point. Defining your ownership goals is perhaps the hardest part of owning forested land. 


\section{Roads}

- Include a map of your road system. Identify road easements or existing encroachment permits, if needed to access county roads. Assess roads for problems and usage. Make recommendations for improving, developing, maintaining, and retiring roads to ensure good water quality and fish habitat. Take into account road locations; surface and road stability; stream crossings and potential for sediment delivery to streams; and culvert size, condition, and ability for passage of fish, if present. Identify water quality and soil productivity impacts associated with your roads and how these will be addressed.

- Identify whether each road provides seasonal or permanent access and whether you provide the essential maintenance. Identify road needs such as relocation, rebuilding, and resurfacing, and maintenance needs such as water bars, rolling dips, culvert cleaning, and ditching. Identify expected future road needs.

\section{Water Resources}

- Identify the boundaries of the main watershed(s) that contain your property. List the named streams (even if not present on your property) that drain the property and the next larger stream for each. Identify and map streams and springs. Identify water rights for both the property and registered domestic downstream water use. Identify easements for water rights. Assess and evaluate ponds for leakage and possible dike failure. Identify ponds and other locations for drafting water for fire protection.

- Identify riparian areas and wetlands and describe their vegetation, conditions, and opportunities for management or restoration. Consider opportunities for coordinated management with neighbors.

\section{Forest Health}

- Identify insect, disease, and animal damage, as well as wildfire issues and associated management strategies to resolve problems. Note on forest maps pest management concerns, fuel levels, and stands vulnerable to wind damage.

\section{Fire Plan}

- Determine what fire protection district the property is in and whether there is a local fire safe council. Provide a fire management plan that includes road accessibility, road width and turnaround locations, fuel breaks and other safe locations for firefighters, and evacuation routes. The fire plan should indicate locations for water drafting, volume of water supply, and compatibility with firefighter equipment (i.e., type and diameter of fittings of existing water storage tanks and hoses), fuel reduction plans, tree thinning, tree pruning, and creation of defensible space around structures. Note and map fuel levels in the forest.

\section{Vegetation Management}

- Describe your plans, if any, for timber harvest, including silvicultural treatments and systems and logging conditions.

- Describe local markets to buy your potential products and transportation to them.

- Discuss required permits, rotation and cutting cycle, allowable cut, cutting budget, and order.

- Describe the steps you will take to improve forest health, such as pest protection measures, stand improvement, and reforestation.

- Would forest certification or involvement in a carbon banking system be a benefit to you?

\section{Agroforestry and Range}

- Identify any resources, opportunities, and projected costs and revenues for a potential business plan. 


\section{Special Forest Products}

- Note possible special forest products (greenery, mushrooms, carbon storage, hunting leases, etc.) available on your property and determine what markets exist. Develop a business and marketing plan.

\section{Archaeological and Cultural Resources}

- You are the steward of the past. Preserve family, community, and local history. Identify cabins, buildings, and prehistoric sites, and sites more than 50 years old. List measures needed to protect known resources. Contact the California Office of Historic Preservation (OHP) for more information and the California Department of Forestry and Fire Protection (CAL FIRE) for information on requirements to protect resources such as Native American sites, trails, cemeteries, homesteads, and other significant sites.

\section{Recreation}

- Identify recreational resources and describe opportunities. Identify trails on maps and assess their condition. Fire safety must be addressed in recreation planning. Include anticipated costs and revenues.

\section{Aesthetic and Scenic}

- Describe opportunities to meet your aesthetic and scenic objectives. Note scenic highways, parks, or rivers abutting the property. Identify management opportunities to improve aesthetics.

\section{Forest Practice Rules}

- All management recommendations must follow the regulatory rules. Identify what rules apply to your management plans, what permits are required, and the lead agency to contact.

\section{Assistance}

- Identify assistance needed to accomplish objectives and possible sources of financial, technical, and educational assistance. List contacts.

- Identify your RPF, certified public accountant, lawyer, and other professionals.

\section{Taxes and Business Management}

- Discuss your tax situation, including record keeping, current tax status, federal and state income tax, and land use classification. Have you made an estate plan? Is a conservation easement appropriate?

\section{Summary of Resource Situation}

- Describe resource situations and management opportunities for each management unit. These may include short- and long-term recommendations. Where applicable, address financial aspects, tax implications, estate planning, and assistance needed. Show timing and priority of management recommendations.

\section{Measuring success in meeting your objectives}

- How will you evaluate your efforts to meet your goals and objectives? Do you have a program for monitoring and adaptive management?

\section{Appendices}

- Maps, lists, pictures (including permanent photo points), etc.

\section{Conclusions}

Any type of management plan will be of great benefit to you now and into the future. Whether you are trying to acquire a bank loan, assistance program, state-approved harvesting permit, or estate plan, each begins with an understanding of your vision and 
goals. Furthermore, this document becomes to basis to communicate to future generations.

\section{FOR FURTHER INFORMATION}

To order or obtain printed ANR publications and other products, visit the ANR Communication Services online catalog at http://anrcatalog.ucdavis.edu. You can also place orders by mail, phone, or FAX, or request a printed catalog of our products from:

University of California

Agriculture and Natural Resources

Communication Services

6701 San Pablo Avenue, 2nd Floor

Oakland, California 94608-1239

Telephone: (800) 994-8849 or (510) 642-2431

FAX: (510) 643-5470

E-mail inquiries: danrcs@ucdavis.edu

An electronic version of this publication is available on the ANR Communication Services Web site at http://anrcatalog.ucdavis.edu.

Publication 8248

ISBN-13: 978-1-60107-468-3

(C) 2007 by the Regents of the University of California, Division of Agriculture and Natural Resources. All rights reserved.

The University of California prohibits discrimination or harassment of any person on the basis of race, color, national origin, religion, sex, gender identity, pregnancy (including childbirth, and medical conditions related to pregnancy or childbirth), physical or mental disability, medical condition (cancer-related or genetic characteristics), ancestry, marital status, age, sexual orientation, citizenship, or status as a covered veteran (covered veterans are special disabled veterans, recently separated veterans, Vietnam era veterans, or any other veterans who served on active duty during a war or in a campaign or expedition for which a campaign badge has been authorized) in any of its programs or activities. University policy is intended to be consistent with the provisions of applicable State and Federal laws.

Inquiries regarding the University's nondiscrimination policies may be directed to the Affirmative Action/Staff Personnel Services Director, University of California, Agriculture and Natural Resources, 300 Lakeside Drive, 6th Floor, Oakland, CA 94612-3550 (510) 987-0096. For a free catalog of other publications, call (800) 994-8849. For help downloading this publication, call (530) 297-4445.

This publication has been anonymously peer reviewed for technical accuracy by University of California scientists and other qualified professionals. This review process was managed by the ANR Associate Editor for Natural Resources.

pr-12/07-SB/CM 